\title{
Glycidyl methacrylate macroporous copolymer grafted with diethylene triamine as sorbent for Reactive Black 5
}

\author{
Zvjezdana P. Sandić ${ }^{1}$, Marija J. Žunić ${ }^{2}$, Danijela D. Maksin ${ }^{3}$, Aleksandra D. Milutinović-Nikolić \\ Aleksandar R. Popović ${ }^{4}$, Dušan M. Jovanović ${ }^{2}$, Aleksandra B. Nastasović ${ }^{5}$ \\ ${ }^{1}$ University of Banja Luka, Faculty of Science, Banja Luka, Bosnia and Herzegovina (Republic of Srpska) \\ ${ }^{2}$ University of Belgrade, ICTM - Department of Catalysis and Chemical Engineering, Belgrade, Serbia \\ ${ }^{3}$ University of Belgrade, Vinča Institute of Nuclear Sciences, Department of Chemical Dynamics and Permanent \\ Education, Belgrade, Serbia \\ ${ }^{4}$ University of Belgrade, Faculty of Chemistry, Belgrade, Serbia \\ ${ }^{5}$ University of Belgrade, ICTM - Department of Chemistry, Belgrade, Serbia
}

\begin{abstract}
In this paper, macroporous glycidyl methacrylate and ethylene glycol dimethacrylate copolymer functionalized with diethylene triamine (PGME-deta), was evaluated as Reactive Black 5 (RB5) sorbent. Batch RB5 removal from aqueous solution by PGME-deta was investigated by varying $\mathrm{pH}$, contact time, sorbent dosage, initial dye concentration and temperature. The sorption is $\mathrm{pH}$ sensitive having maximum at $\mathrm{pH} 2$ (dye removal of $85 \%$ ), decreasing with the increase of $\mathrm{pH}$ (dye removal of $24 \%$ at $\mathrm{pH} 11$ ) after $60 \mathrm{~min}$. Sorption kinetics was fitted to chemical-reaction and particle-diffusion models (pseudo-first-, pseudo-second-order, intraparticle diffusion and Mckay models). The pseudo-second-order kinetic model accurately predicted the RB5 amount sorbed under all investigated operating conditions, while the intraparticle diffusion was the dominant rate-limiting mechanism. The diffusion mechanism was more prevalent with the decrease in temperature and the increase in concentration. The isotherm data was best fitted with the Langmuir model, indicating homogeneous distribution of active sites on PGME-deta and monolayer sorption, with the maximum sorption capacity of $353 \mathrm{mg} \mathrm{g}^{-1}$. The calculated sorption rates improved with increasing temperature and an activation energy close to $40 \mathrm{~kJ} \mathrm{~mol}^{-1}$ was determined, suggesting that chemisorption was also rate-controlling.
\end{abstract}

Keywords: Reactive Black 5, macroporous crosslinked copolymer, diethylene triamine, kinetic modeling, equilibrium study.
Polymers

\section{SCIENTIFIC PAPER}

UDC 677.027.4:678-13:547:66

Hem. Ind. 68 (6) 685-699 (2014)

doi: 10.2298/HEMIND140127023S

Available online at the Journal website: http://www.ache.org.rs/HI/

Surface and groundwater pollution by industrial waste is widespread in highly industrialized countries due to direct discharge of such effluents into water bodies or by precipitation of air-borne pollutants into surface waters [1]. In general, dyes are the most easily detected pollutants in the industrial effluents since they are innately highly visible, meaning that concentrations as low as $0.005 \mathrm{mg} \mathrm{dm}^{-3}$ will seize the attention of public [2]. There is a variety of synthetic dyes appearing in the effluents of wastewaters in numerous industries such as textiles, leather, paper-making, plastics, food, rubber, pharmaceuticals and cosmetics with annual production of $7 \times 10^{8} \mathrm{~kg}$ [3]. Reactive dyes, the most frequently used due to their bright colors, excellent colorfastness and ease of application pose a serious threat to human health due to their carcinogenic,

Correspondence: A. Nastasović, University of Belgrade, Institute of Chemistry, Technology and Metallurgy, Center for Chemistry, Njegoševa 12, 11000 Belgrade, Serbia.

E-mail: anastaso@chem.bg.ac.rs; anastasovic@yahoo.com

Paper received: 27 January, 2014

Paper accepted: 18 March, 2014 mutagenic and toxicological effects on organisms [4]. The presence of small amounts of dyes in water blocks the passage of light and significantly affects photosynthetic activity in aquatic life [5]. The current estimation is that $2 \%$ of dyes are discharged directly in aqueous effluents during the production process of these dyes [6].

Methods for dye removal from dye-containing industrial effluents generally include chemical (oxidative processes, use of Fenton's reagent, ozonation, photochemical and electrochemical destruction), physical (sorption, membrane filtration and electrokinetic coagulation) and biological methods (decolorization by microbial cultures and sorption by living/dead microbial biomass) [6]. Sorption techniques have gained favor recently due to their efficiency for the removal of persistent pollutants unaffected by the conventional methods. Decolorization is the result of two mechanisms: sorption and ion exchange [7], influenced by dye/sorbent interaction, sorbent surface area, particle size, temperature, $\mathrm{pH}$, and contact time [8]. A wide variety of sorbents, like activated carbon and bone char $[6,9]$, beet pulp carbon [10], clay and peat [6], fly ash 
[11], chitin/chitosan [12,13], synthetic polymers [3] and others have been suggested for textile dye removal from wastewaters. Polymeric sorbents have been increasingly investigated as a potential alternative to activated carbon due their controllable pore structure, stable physical and chemical properties, as well as their ability to be regenerated and reused [14]. Macroporous hydrophilic copolymers based on glycidyl methacrylate, GMA, produced by radical suspension copolymerization as regular beads of required size and porosity are very attractive, since the epoxy group can be easily transformed under mild reaction conditions into amino, iminodiacetate, thiol, azole and pyrazole, pyridine groups, etc. The porous structure of these copolymers can be controlled and optimized by adjusting the reaction mixture composition [15]. Amino-functionalized GMA-based macroporous copolymers proved to be very useful for sorption of heavy and precious metals [16], radionuclides [17] and textile dyes [3,18,19].

In this paper, macroporous copolymer of GMA and ethylene glycol dimethacrylate, EGDMA (PGME) additionally functionalized via ring-opening reaction of the pendant epoxy groups with diethylene triamine (PGME-deta), was tested as Reactive Black 5 (RB5) sorbent. The effects of the $\mathrm{pH}$, sorbent dosage, contact time and temperature on the sorption properties of PGME-deta in RB5 removal from aqueous solutions were studied in order to evaluate this material as a potential dye wastewater sorbent. Sorption kinetic data were analyzed using four kinetic models (pseudo-first, pseudo-second-order, intraparticle diffusion and Mckay models) to determine the best fit equation for RB5 sorption by amino-functionalized PGME.

\section{MATERIALS AND METHODS}

\section{Materials}

All the chemicals used for copolymer synthesis were analytical grade products and used as received: glycidyl methacrylate (Aldrich, Germany), ethylene glycol dimethacrylate (Aldrich, Germany), diethylene triamine (Sigma-Aldrich Chemie GmbH, Germany), 2,2'-azobisiso-butyronitrile, AIBN (Aldrich, Germany), poly( $N$-vinyl pyrrolidone) (Kolidon 90, BASF, Fine chemicals, Switzerland), cyclohexanol (Sigma-Aldrich Chemie GmbH, Germany) and dodecanol (Sigma-Aldrich Chemie $\mathrm{GmbH}$, Germany). Synthetic textile dye, Reactive Black 5 (Alfa-Aesar, USA) having chemical purity of ca. $55 \%$ was used without further purification as test dye.

\section{Methods}

The epoxy group content in the synthesized PGME was determined by $\mathrm{HCl}$-dioxane method [20]. The amino-functionalized sample was analyzed for carbon, hydrogen and nitrogen content using the Vario EL III device (GmbH Hanau Instruments, Germany). The degree of conversion of the epoxy groups and the amino group concentration in PGME-deta were calculated from elemental analysis data. The pore size distribution was determined by mercury porosimetry (Carlo Erba 2000, Milestone 200 software). The sample was dried at $323 \mathrm{~K}$ for $8 \mathrm{~h}$ and degassed at room temperature and pressure of $0.5 \mathrm{~Pa}$ for $2 \mathrm{~h}$.

The $\mathrm{pH}$ drift method [21] was used to determine the $\mathrm{pH}$ at point zero charge $\left(\mathrm{pH}_{\mathrm{PZC}}\right)$ of the PGME-deta surface using $20 \mathrm{~cm}^{3}$ of $0.01 \mathrm{M} \mathrm{NaCl}$ in a series of Erlenmeyer flasks, where the $\mathrm{pH}$ values were adjusted using $0.1 \mathrm{M} \mathrm{NaOH}$ and $0.1 \mathrm{M} \mathrm{HCl}$ in the range between 2 and 12 with a Jenway $3320 \mathrm{pH}$ meter. The initial $\mathrm{pH}$ of the solutions $\left(\mathrm{pH}_{\mathrm{i}}\right)$ was determined and $50.0 \mathrm{mg}$ of the polymer was added to each of the flasks. The mixtures were shaken for $24 \mathrm{~h}$ and the final $\mathrm{pH}$ values of the solutions $\left(\mathrm{pH}_{\mathrm{f}}\right)$ were measured. $\mathrm{pH}_{\mathrm{pzc}}$ was recorded as the $\mathrm{pH}$ value in which the initial $\mathrm{pH}$ equals the final $\mathrm{pH}$ [22].

\section{Preparation of poly(GMA-co-EGDMA) and functionalization with diethylene triamine}

Macroporous PGME sample was prepared by radical suspension copolymerization of GMA and EGDMA, in the presence of inert component (90 mass\% of cyclohexanol and 10 mass\% dodecanol) as described previously [23]. Particles with diameters in the range 0.15$-0.30 \mathrm{~mm}$ were functionalized with diethylene triamine. A mixture of $3.6 \mathrm{~g}$ of PGME, $15.7 \mathrm{~g}$ of diethylene triamine and $100 \mathrm{~cm}^{3}$ of toluene was left at room temperature for $24 \mathrm{~h}$ then heated at $353 \mathrm{~K}$ for $6 \mathrm{~h}$. The modified sample was filtered, washed with ethanol, dried and labeled as PGME-deta (additional label -deta designates sample functionalized with diethylene triamine) [24].

\section{Dye sorption experiments}

The sorption of RB5 by PGME-deta was investigated in aqueous solutions in batch mode, either in a thermostated shaker (Memmert WNE 14 and SV 1422) or in a Pyrex beaker (thermostated by Julabo F 25 with circular heater and cooler) which was equipped with a magnetic stirrer. The same volume of the solution (50.0 $\mathrm{cm}^{3}$ ) was used in all the experiments. The effects of $\mathrm{pH}$ and sorbent dosage were investigated at the initial dye concentration $c_{0}=50 \mathrm{mg} \mathrm{dm}^{-3}$ and room temperature (298 K) using magnetic stirring. The $\mathrm{pH}$ value was adjusted by addition of the appropriate amounts of $1 \mathrm{M} \mathrm{HCl}$ or $1 \mathrm{M} \mathrm{NaOH}$.

Magnetic stirring was also used for the investigation of the influence of the initial dye concentration $\left(c_{0}, 30-\right.$ $-150 \mathrm{mg} \mathrm{dm}^{-3}$ ) at $298 \mathrm{~K}$. For contact time studies the samples were taken at predetermined time intervals $(10,20,30,60,120,180 \mathrm{~min}$ and $24 \mathrm{~h})$. The effect of temperature on the sorption was evaluated with the selected initial dye concentrations $\left(c_{0}, 50-90 \mathrm{mg} \mathrm{dm}^{-3}\right)$ 
at four different temperatures $(288,298,308$ and 318 $\mathrm{K})$, up to $24 \mathrm{~h}$.

Sorption isotherms were obtained in the shaker, by placing $25.0 \mathrm{mg}$ of copolymer in contact with a series of RB5 solutions in the concentration range 175-1500 mg $\mathrm{dm}^{-3}$, at room temperature and unadjusted $\mathrm{pH}$. Equilibrium time was $24 \mathrm{~h}$.

The amount of dye sorbed by the sorbent at time $t$, $Q_{t}\left(\mathrm{mg} \mathrm{g}^{-1}\right)$, was calculated by the following mass balance relationship:

$Q_{t}=\frac{\left(c_{0}-c_{t}\right) V}{m}$

Where: $c_{t}$ is dye solution concentrations ( $\mathrm{mg} \mathrm{dm}^{-3}$ ) after sorption time $t, V$ is the volume of the aqueous phase $\left(\mathrm{dm}^{3}\right)$ and $m$ is the amount of the PGME aminofunctionalized beads used for the experiment $(\mathrm{g})$.

The solution samples were withdrawn at the specified time intervals, dye solution was centrifuged and the absorbance of the supernatant solution was measured. The spectra were obtained using Thermo Electron Nicolet Evolution 500 UV-Vis spectrophotometer and the absorption peak of RB5 at $597 \mathrm{~nm}$ was chosen for monitoring the sorption process.

Standard statistical methods were applied to calculate the mean values and standard deviations for each set of data. All experiments were repeated in triplicate or more if necessary. Relative standard deviations were less than or equal to $5 \%$.

\section{RESULTS AND DISCUSSION}

\section{Characterization of sorbents}

Relevant physicochemical characteristics of amino-functionalized copolymer sample PGME-deta are given in Table 1 . The degree of conversion of $40 \%$ was expected, since similar values were already obtained for reaction with ethylene diamine $(50 \%)$, and triethylene tetramine (31\%) [24].

Table 1. Relevant characteristics of amino-functionalized copolymer sample PGME-deta [18]

\begin{tabular}{lc}
\hline Property & Value \\
\hline$S_{\mathrm{s}, \mathrm{Hg}} / \mathrm{m}^{2} \mathrm{~g}^{-1}$ & 53 \\
$V_{\mathrm{S}} / \mathrm{cm}^{3} \mathrm{~g}^{-1}$ & 0.635 \\
$D_{V / 2} / \mathrm{nm}$ & 59 \\
$D_{\mathrm{av}} / \mathrm{nm}$ & 50 \\
Degree of conversion of epoxy groups, \% & 40 \\
Ligand concentration, mmol g & 1.67 \\
Amino group concentration, $\mathrm{mmol} \mathrm{g}^{-1}$ & 5.01 \\
\hline
\end{tabular}

The porosity parameters, i.e., the values of specific pore volume $\left(V_{s}\right)$ average pore diameter $\left(D_{\mathrm{av}}\right)$ and pore diameter which corresponds to half of pore volume
$\left(D_{V / 2}\right)$ were read from the pore size distribution curves, while the specific surface area $\left(S_{\mathrm{S}, \mathrm{Hg}}\right)$ was calculated as the sum of incremental specific surface areas from the pore size distribution curves as described in the literature [25].

\section{Effect of $\mathrm{pH}$}

The initial $\mathrm{pH}$ of the sorbate/sorbent system is a critical process parameter because the aqueous chemistry and the surface binding sites of the sorbent are dependent on the $\mathrm{pH}$ value of the mixture. The sorption of dye ions on the sorbent surface is primarily influenced by the surface charge of the sorbent, which in turn is influenced by the solution $\mathrm{pH}$. The effect of the solution $\mathrm{pH}$ on the dye uptake can be rationalized on the basis of $\mathrm{pH}_{\mathrm{PZC}}$ of the copolymer [26]. $\mathrm{pH}_{\mathrm{PZC}}$ by definition is the value of $\mathrm{pH}$ when the overall charge on the sorbent surface is zero. This is a convenient indicator of either positive or negative charge of the sorbent surface as a function of $\mathrm{pH}$. When the $\mathrm{pH}$ value of the mixture of PGME-deta and RB5 solution is lower than $\mathrm{pH}_{\mathrm{PZC}}$, it means that the sorbent surface is positively charged. If the $\mathrm{pH}$ of the mixture is higher than $\mathrm{pH}_{\mathrm{PZC}}$, the surface would be negatively charged.

The RB5 dye is an acidic dye with a complex molecule (Scheme 1) that consists of two benzene rings and one naphthalene ring, incorporating two azo (chromophore) groups, accountable for the coloring, and auxochrome and anti-auxochrome groups (sulpho, amino, hydroxyl, methyl, etc.), which contribute to the richness of the color [27]. Two sulfonate groups and another two sulfatoethylsulfone group are negatively charged even in very acidic solutions, as a result of their $\mathrm{p} K_{\mathrm{a}}<0$ [28].<smiles>Nc1c(/N=N/c2ccc(S(=O)(=O)CCOS(=O)(=O)O)cc2)c(S(=O)(=O)[O-])cc2cc(S(=O)(=O)[O-])c(N=Nc3ccc(S(=O)(=O)CCOS(=O)(=O)[O-])cc3)c(O)c12</smiles>

Scheme 1. Structure of RB5 dye in aqueous solution.

The effect of $\mathrm{pH}$ on the RB5 sorption by PGME-deta and the $\mathrm{pH}_{\mathrm{PZC}}$ of PGME-deta is shown in Fig. 1. The size of the dye molecules and its ability to form negatively charged species have an effect on its sorption from solution onto the sorbent [1]. The $\mathrm{pH}$ values in this experiment were varied between 2 and 11, keeping other parameters constant. The $\mathrm{pH}_{\mathrm{PZC}}$ of PGME-deta determined by the $\mathrm{pH}$ drift method was approximately 7.7 


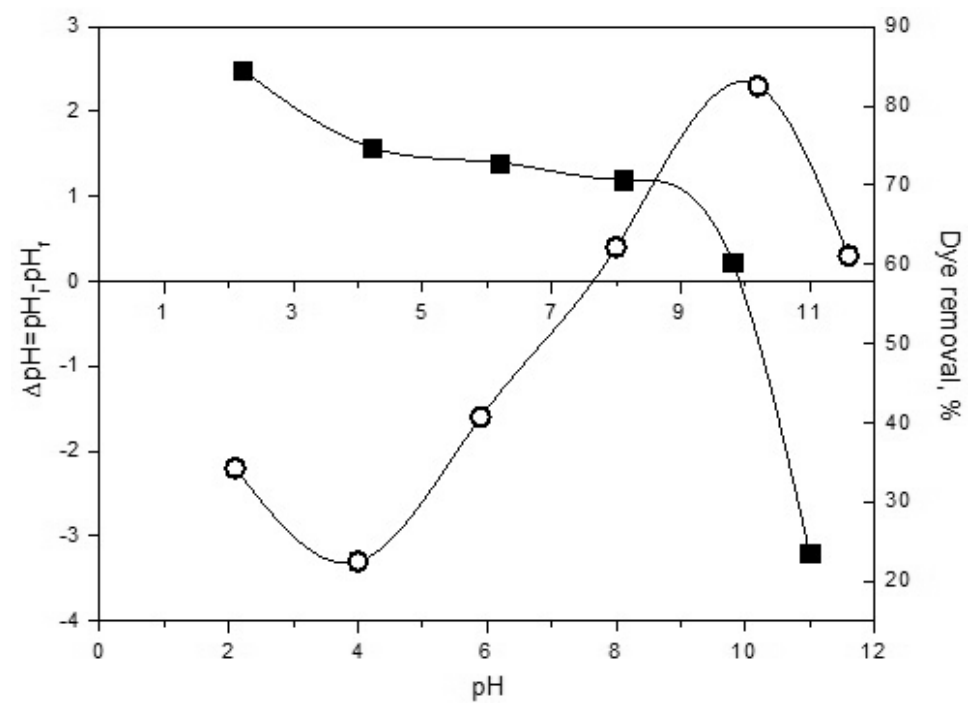

Figure 1. Effect of $\mathrm{pH}$ on the RB5 sorption by PGME-deta and $p H_{P Z C}$ measurement of PGME-deta $\left(c_{0}=50 \mathrm{mg} \mathrm{dm}{ }^{-3}, T=298 \mathrm{~K}\right.$, $t=60 \mathrm{~min}$ ); dye removal - black squares; $\Delta \mathrm{pH}$ - white circles.

(Fig. 1). Consequently, at acidic $\mathrm{pH}$ values, there is attraction between the PGME-deta particle with its protonated amino groups and the negative RB5 dye ion. As long as the RB5 solution $\mathrm{pH}<\mathrm{pH}_{\mathrm{PZC}}$, its surface would bring an overall positive charge. However, there is significant dye removal at $\mathrm{pH}<\mathrm{pH}_{\mathrm{Pzc}}$. Accordingly, electrostatic attraction mechanism must be included as a significant but not the only factor in RB5 sorption by PGME-deta. Özcan and Özcan previously established that at strongly acidic $\mathrm{pH}$ values exists a major electrostatic attraction between the positively charged sorbent surface and anionic dyes [29]. In contrast, negatively charged sorbent surface sites do not promote the sorption of dye anions, due to the electrostatic repulsion. In a highly acidic solution $(\mathrm{pH} 2)$, a high concentration of positively charged protonated amino groups exists on the surface of PGME-deta, and interaction occurs with four negatively charged sulfonic groups of RB5 ( $85 \%$ dye removal). At $\mathrm{pH}$ values around 11 , negatively charged hydroxyl ions compete with the dye resulting in the inhibition of RB5 sorption on PGME-deta surface and a low percent removal was noted (24\%). The exceptionally slow decrease in dye removal in the $\mathrm{pH}$ range of $4-8$ (from 75 to $71 \%$ ) might be associated with the fact that the sorption mechanisms above mentioned are affected indistinctively by a change of $\mathrm{pH}$ in this region [22]. The $\mathrm{p} K_{\mathrm{a}}$ value of amine groups typically lies within the range 8-11 [30], implying that the amine groups are fully protonated at $\mathrm{pH}<5$ and that the extent of protonation slowly decreases with the increase in $\mathrm{pH}$, accounting for the phenomenon. It is very likely that predominantly hydrogen bonds are being formed between dye molecules and neutral amino groups at $\mathrm{pH}$ values higher than $8[17,30]$.

Considering that the main goal of this research was synthesis of a sorbent for purification of the dye pro- duction industry wastewaters which already have fluctuating $\mathrm{pH}$ values, $\mathrm{pH}$ adjustment of the working solution would mean an additional operation which would increase the procedure cost and cause an ecological problem. Therefore, the further sorption investigations were carried out at the unadjusted $\mathrm{pH}$ value of 5.5, being less efficient but satisfactory. The usual $\mathrm{pH}$ values in surface water systems fall between 6.5 and 8.5 and for groundwater systems between 6 and 8.5 [31], thus these conditions appear to be quite close to optimal for effluent treatment due to the near neutral $\mathrm{pH}$ of the final discharge after sorption.

\section{Effect of sorbent dosage}

In order to determine the optimal quantity of PGME-deta required for RB5 sorption, the influence of sorbent dosage and sorption capacity after $60 \mathrm{~min}\left(Q_{60}\right)$ on dye removal was investigated at room temperature and presented in Figure 2.

As can be seen, the RB5 removal was observed to be dependent on the PGME-deta dosage. The percent of dye removal sharply increased from 0.1 up to $1.0 \mathrm{~g}$ $\mathrm{dm}^{-3}$, and for higher sorbent doses it reached the plateau of $100 \%$ dye removal. In contrast, as expected due to the variation in the concentration gradient, the sorption uptake increased with decreasing PGME-deta dosage, and the maximum sorption capacity of $86 \mathrm{mg} \mathrm{g}^{-1}$ was obtained for $0.1 \mathrm{~g} \mathrm{dm}^{-3}$. The increase of percent dye removal with the increased sorbent dosage can be ascribed to the enhanced sorbent surface area and the availability of more sorption sites with the increase of sorbent content, thus leading to a higher interaction between PGME-deta particles and RB5 molecules [32]. For further experiments, the mass of $25.0 \mathrm{mg}$, i.e., the dose of $0.5 \mathrm{~g} \mathrm{dm}^{-3}$ of PGME-deta was chosen for the 


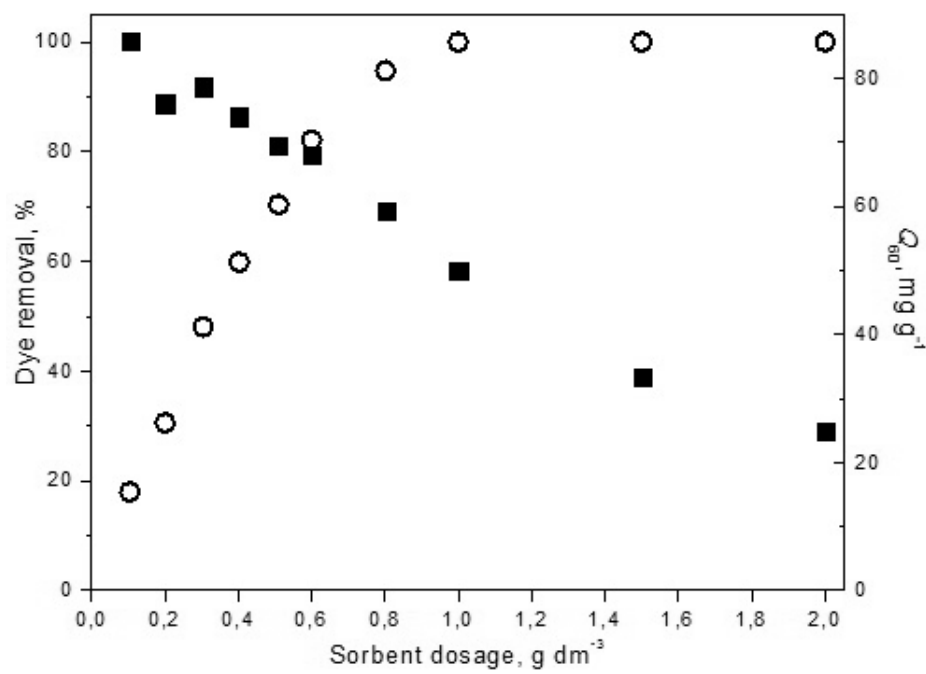

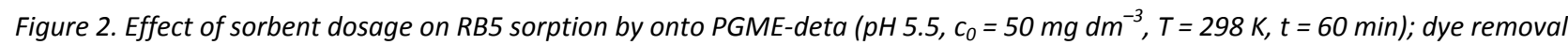
- white circles; $Q_{60}-$ black squares.

purpose of comparison with previous results and reducing the cost of the potential practical application [18].

\section{Effect of contact time}

Since dye sorption is a time-dependent process, the effect of contact time on the amount of RB5 sorbed by PGME-deta (Figure 3) was investigated.

The rate of RB5 removal by PGME-deta was high initially and the process then gradually slowed down. The time profile of dye sorption by PGME-deta was a single continuous curve leading to saturation, suggesting the possible monolayer coverage of RB5 on the sorbent surface [33]. With the increased initial concentrations the saturation was reached at prolonged sorption times. For $c_{0}=30$ and $50 \mathrm{mg} \mathrm{dm}^{-3}$, the sorption equilibrium was reached after $180 \mathrm{~min}$, while for the higher initial concentrations the time necessary for equilibrium attainment was prolonged to $24 \mathrm{~h}$.
As an illustration, in Table 2 are presented the data on removal efficiency $(R E)$ for selected initial concentrations.

Table 2. Removal efficiency (\%) for indicated RB5 initial concentrations at $298 \mathrm{~K}$

\begin{tabular}{lcccc}
\hline \multirow{2}{*}{$t / \min$} & \multicolumn{4}{c}{$c_{0} / \mathrm{mg} \mathrm{dm}^{-3}$} \\
\cline { 2 - 5 } & 30 & 50 & 70 & 130 \\
\hline 60 & 90 & 82 & 78 & 66 \\
120 & 99 & 97 & 94 & 82 \\
180 & 100 & 100 & 99 & 95 \\
\hline
\end{tabular}

\section{Effect of temperature}

Kinetic studies were also carried out at different temperatures $(288-318 \mathrm{~K})$ and the sorption process was found to accelerate with increasing temperature

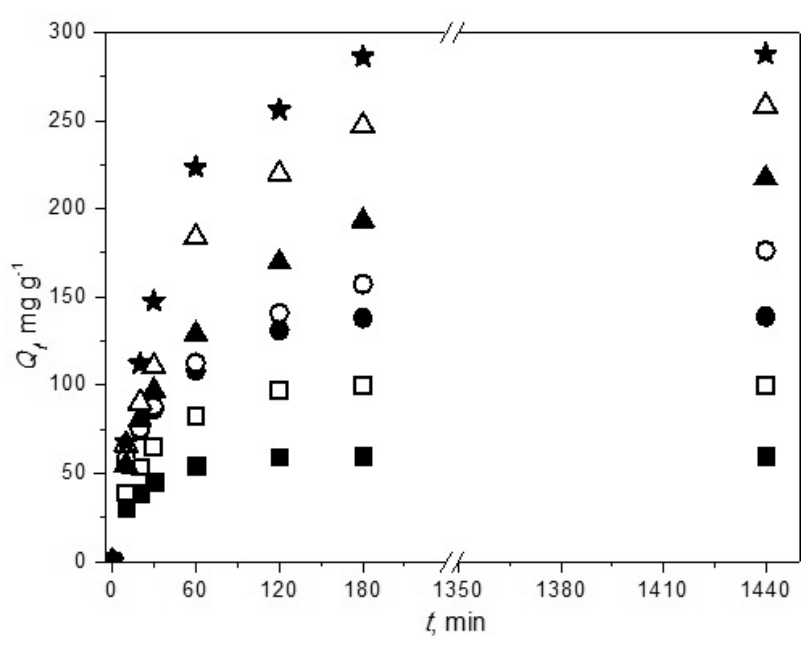

Figure 3. Effect of contact time on RB5 sorption by PGME-deta at different initial concentrations $\left(0.5 \mathrm{~g} \mathrm{dm}^{-3}, \mathrm{pH} 5.5, T=298 \mathrm{~K}\right)$; $30 \mathrm{mg} \mathrm{dm}$ - black squares; $50 \mathrm{mg} \mathrm{dm}{ }^{-3}$ - white squares; $70 \mathrm{mg} \mathrm{dm^{-3 }}$ - black circles; $90 \mathrm{mg} \mathrm{dm}^{-3}$ - white circles; $110 \mathrm{mg} \mathrm{dm}^{-3}$ -

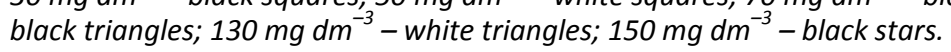


(Figure 4). It was also observable from the graphs that the half-life of each process decreased with increasing temperature, which verified that the continuing process was of endothermic nature.

As an illustration, the data on RE for the initial concentration of $90 \mathrm{mg} \mathrm{dm}^{-3}$ is presented in Table 3. The equilibrium sorption capacity of RB5 on PGME-deta was not at all affected by temperature in the investigated concentration range (50-90 $\mathrm{mg} \mathrm{dm}^{-3}$ ), inside the experimental error. However, for higher temperatures the equilibrium sorption capacity was achieved faster. It should be noted that $100 \%$ RE was achieved for all three initial concentrations at all four temperatures within $24 \mathrm{~h}$.

Table 3. Removal efficiency (\%) for RB5 at different temperatures for initial concentration of $90 \mathrm{mg} \mathrm{dm}^{-3}$

\begin{tabular}{lcccc}
\hline \multirow{2}{*}{$t / \min$} & \multicolumn{4}{c}{$T / \mathrm{K}$} \\
\cline { 2 - 5 } & 288 & 298 & 308 & 318 \\
\hline 60 & 60 & 64 & 79 & 80 \\
120 & 79 & 80 & 97 & 97 \\
180 & 93 & 89 & 100 & 100 \\
\hline
\end{tabular}

\section{Sorption dynamics}

The sorption kinetics is essential for implementation since it controls the overall process efficiency and provides insight into sorption mechanism.

\section{Surface reaction-based models}

Since the pseudo-first (PFO) and the pseudo-second-order (PSO) kinetic models are the most commonly used to determine kinetic parameters of sorption processes for various solute/sorbent combinations, the kinetic data in this study were treated with both models $[34,35]$. The integrated rate laws for pseudofirst-order and pseudo-second-order reactions in linear form are presented in Eqs. (2) and (3), respectively: $\log \left(Q_{e}-Q_{t}\right)=\log Q_{e}-\frac{k_{1} t}{\ln 10}$

$\frac{t}{Q_{t}}=\frac{1}{k_{2} Q_{\mathrm{e}}^{2}}+\frac{1}{Q_{\mathrm{e}}} t$

$h=k_{2} Q_{e}^{2}$

where $Q_{t}$ is the amount of sorbed dye $\left(\mathrm{mg} \mathrm{g}^{-1}\right)$ at any time $t, Q_{\mathrm{e}}$ is the amount of sorbed dye at equilibrium $\left(\mathrm{mg} \mathrm{g}^{-1}\right), k_{1}$ is the PFO rate constant $\left(\mathrm{min}^{-1}\right), k_{2}$ is the PSO rate constant ( $\mathrm{g} \mathrm{mg}^{-1} \mathrm{~min}^{-1}$ ), $h$ (defined by Eq. (4)) is initial sorption rate from PSO model $\left(\mathrm{mg} \mathrm{g}^{-1} \mathrm{~min}^{-1}\right)$.

The values for $Q_{e}, k_{1}$ and $k_{2}, h$, as well as the corresponding coefficients of determination $\left(R^{2}\right)$ for each initial dye concentration are presented in Table 4 and for each temperature in Table 5 . The values for $k_{1}$ were calculated from the plots of $\log \left(Q_{e}-Q_{t}\right)$ vs. $t$ for each initial dye concentration, while $k_{2}$ and $h$ were calculated from the $t / Q_{t} v s$. $t$ plot. The compliance of experimental data with the model-predicted values was judged against the $R^{2}$ values. Also, the values of $Q_{e}$ obtained from the experimental data were compared with those calculated from PFO and PSO reaction kinetic plots.

Table 4 illustrates that $k_{1}$ and $k_{2}$ changed with variation in concentration of the dye in solution. However, according to the Arrhenius equation the rate constant of a reaction changes only with change in temperature kinetics, and it never varies with differing concentrations of reactant species [36]. PSO generated higher $R^{2}$ values $(\geq 0.999)$ than PFO model for all investigated concentrations and temperatures and the predicted values of $Q_{e}^{\text {calc }}$ agreed well with the experimental values. From this it can be inferred that the kinetics of this sorbate/sorbent system is accurately described by this model at all time intervals, indicating that the sorption rate is controlled by both the sorbent capacity and the sorbate concentration.

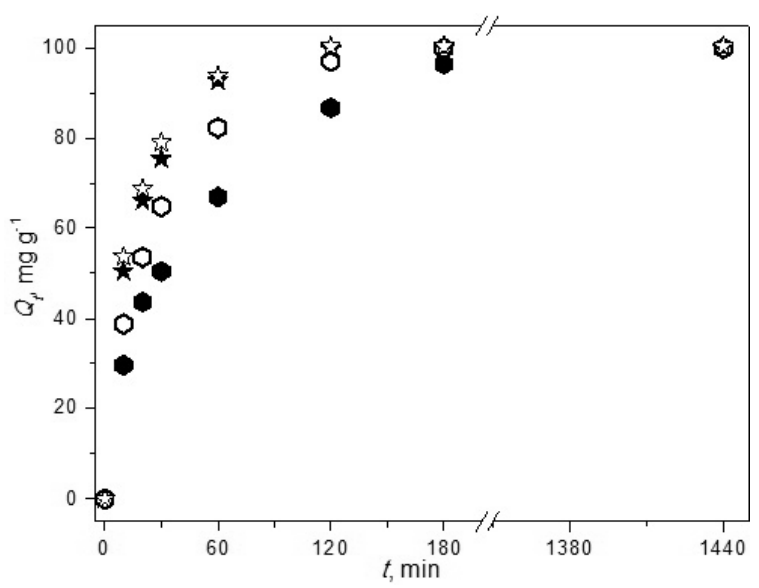

Figure 4. Effect of contact times of RB5 sorption by PGME-deta at different sorption temperatures $\left(0.5 \mathrm{~g} \mathrm{dm}^{-3}, \mathrm{pH} 5.5\right.$, $\left.c_{0}=50 \mathrm{mg} \mathrm{dm}^{-3}\right) ; 288 \mathrm{~K}$-black hexagons; $298 \mathrm{~K}$-white hexagons; $308 \mathrm{~K}$ - black stars; $318 \mathrm{~K}$ - white stars. 
Table 4. Kinetic parameters for RB5 sorption using PGME-deta at different initial dye concentration

\begin{tabular}{|c|c|c|c|c|c|c|c|}
\hline$\overline{c_{\mathrm{i}} / \mathrm{mg} \mathrm{L}^{-1}}$ & 30 & 50 & 70 & 90 & 110 & 130 & 150 \\
\hline$Q_{\mathrm{e}} / \mathrm{mg} \mathrm{g}^{-1}$ & 60.03 & 99.91 & 138.89 & 176.51 & 217.42 & 258.29 & 287.84 \\
\hline \multicolumn{8}{|c|}{ PFO } \\
\hline$k_{1} / \min ^{-1}$ & 0.03963 & 0.02549 & 0.02593 & 0.01123 & 0.01143 & 0.01663 & 0.02623 \\
\hline$Q_{e}^{\text {calc }} / \mathrm{mg} \mathrm{g}^{-1}$ & 51.41 & 80.97 & 124.66 & 137.27 & 184.20 & 237.59 & 316.542 \\
\hline$R^{2}$ & 0.9938 & 0.9908 & 0.9861 & 0.9731 & 0.9878 & 0.9903 & 0.9466 \\
\hline \multicolumn{8}{|c|}{ PSO } \\
\hline$k_{2} \times 10^{3} / \mathrm{g} \mathrm{mg}^{-1} \mathrm{~min}^{-1}$ & 2.395 & 0.8254 & 0.5152 & 0.1898 & 0.1258 & 0.1230 & 0.2500 \\
\hline$h / \mathrm{mg} \mathrm{g}^{-1} \min ^{-1}$ & 8.723 & 8.397 & 10.15 & 6.156 & 6.247 & 9.054 & 21.14 \\
\hline$t_{1 / 2} / \min$ & 6.9 & 12.0 & 13.8 & 29.3 & 35.7 & 29.1 & 13.8 \\
\hline$Q_{\mathrm{e}}^{\mathrm{calc}} / \mathrm{g} \mathrm{g}^{-1}$ & 60.35 & 100.86 & 140.37 & 180.08 & 222.87 & 263.92 & 290.78 \\
\hline$R^{2}$ & 0.9999 & 0.9999 & 0.9999 & 0.9999 & 0.9990 & 0.9996 & 0.9999 \\
\hline \multicolumn{8}{|c|}{ Intraparticle } \\
\hline$k_{1 \mathrm{id}} / \mathrm{mg} \mathrm{g}^{-1} \mathrm{~min}^{-0.5}$ & 7.806 & 11.28 & 13.56 & 13.16 & 15.52 & 22.01 & 27.12 \\
\hline$c_{1 \mathrm{id}} / \mathrm{mg} \mathrm{g}^{-1}$ & 0 & 0 & 0 & 0 & 0 & 0 & 0 \\
\hline$R^{2}$ & 0.9839 & 0.9953 & 0.9779 & 0.9789 & 0.9928 & 0.9918 & 0.9911 \\
\hline$k_{2 \text { id }} / \mathrm{mg} \mathrm{g}^{-1} \mathrm{~min}^{-0.5}$ & Not applicable & Not applicable & Not applicable & Not applicable & Not applicable & 11.17 & 11.02 \\
\hline$c_{2 \mathrm{id}} / \mathrm{mg} \mathrm{g}^{-1}$ & - & - & - & - & - & 97.29 & 137.35 \\
\hline$R^{2}$ & - & - & - & - & - & 0.9999 & 0.9946 \\
\hline \multicolumn{8}{|c|}{ McKay } \\
\hline $\mathrm{S} / \mathrm{min}^{-1}$ & 0.0397 & 0.0282 & 0.0259 & 0.0112 & 0.0114 & 0.0166 & 0.0262 \\
\hline$R^{2}$ & 0.9938 & 0.9947 & 0.9861 & 0.9731 & 0.9878 & 0.9903 & 0.9466 \\
\hline
\end{tabular}

Table 5. Kinetic parameters for RB5 sorption using PGME-deta at different temperatures

\begin{tabular}{|c|c|c|c|c|c|c|c|c|c|c|c|c|}
\hline$T / \mathrm{K}$ & & 288 & & & 298 & & & 308 & & & 318 & \\
\hline$\overline{c_{\mathrm{i}} / \mathrm{mg} \mathrm{L}^{-1}}$ & 50 & 70 & 90 & 50 & 70 & 90 & 50 & 70 & 90 & 50 & 70 & 90 \\
\hline$\overline{Q_{\mathrm{e}} / \mathrm{mg} \mathrm{g}^{-1}}$ & 100.00 & 139.94 & 179.76 & 99.91 & 138.89 & 176.51 & 99.97 & 140.50 & 179.64 & 100.25 & 137.65 & 177.11 \\
\hline & & & & & PFC & & & & & & & \\
\hline$k_{1} / \min ^{-1}$ & 0.01719 & 0.014603 & 0.01359 & 0.02549 & 0.02593 & 0.01123 & 0.04609 & 0.03450 & 0.02817 & 0.04359 & 0.03632 & 0.03468 \\
\hline$Q_{\mathrm{e}}^{\mathrm{calc}} / \mathrm{mg} \mathrm{g}^{-1}$ & 88.65 & 125.94 & 160.62 & 80.97 & 124.66 & 137.27 & 92.82 & 119.50 & 168.21 & 82.46 & 121.01 & 190.35 \\
\hline$R^{2}$ & 0.9906 & 0.9917 & 0.9857 & 0.9908 & 0.9861 & 0.9731 & 0.9952 & 0.9794 & 0.9916 & 0.9824 & 0.9912 & 0.9825 \\
\hline & & & & & PSC & & & & & & & \\
\hline $\begin{array}{l}k_{2} \times 10^{3} \\
\mathrm{~g} \mathrm{mg}^{-1} \mathrm{~min}^{-1}\end{array}$ & 0.4051 & 0.2270 & 0.1625 & 0.8254 & 0.5152 & 0.1898 & 1.5564 & 0.8593 & 0.3925 & 1.8039 & 0.8696 & 0.4395 \\
\hline$h / \mathrm{mg} \mathrm{g}^{-1} \min ^{-1}$ & 4.197 & 4.653 & 5.508 & 8.397 & 10.15 & 6.156 & 15.71 & 17.19 & 12.95 & 18.29 & 16.70 & 14.06 \\
\hline$t_{1 / 2} / \min$ & 24.3 & 30.8 & 33.4 & 12.0 & 13.8 & 29.3 & 6.4 & 8.2 & 14.0 & 5.5 & 8.3 & 12.7 \\
\hline$Q_{\mathrm{e}}^{\text {calc }} / \mathrm{g} \mathrm{g}^{-1}$ & 101.79 & 143.16 & 184.09 & 100.86 & 140.37 & 180.08 & 100.48 & 141.42 & 181.62 & 100.69 & 138.56 & 178.89 \\
\hline$R^{2}$ & 0.9998 & 0.9996 & 0.9998 & 0.9999 & 0.9999 & 0.9999 & 0.9999 & 0.9999 & 0.9998 & 0.9999 & 0.9999 & 0.9998 \\
\hline & & & & & Intra & article & & & & & & \\
\hline$k_{1 \mathrm{id}} / \mathrm{mg} \mathrm{g}^{-1} \mathrm{~min}^{-0.5}$ & 7.918 & 10.60 & 13.14 & 11.28 & 13.56 & 16.71 & 13.21 & 17.13 & 19.20 & 13.63 & 17.46 & 20.69 \\
\hline$c_{1 \mathrm{id}} / \mathrm{mg} \mathrm{g}^{-1}$ & 0 & 0 & 0 & 0 & 0 & 0 & 0 & 0 & 0 & 0 & 0 & 0 \\
\hline$R^{2}$ & 0.9880 & 0.9971 & 0.9730 & 0.9953 & 0.9779 & 0.8931 & 0.9858 & 0.9864 & 0.9684 & 0.9805 & 0.9904 & 0.9518 \\
\hline & & & & & McK & & & & & & & \\
\hline $\mathrm{S} / \mathrm{min}^{-1}$ & 0.01719 & 0.01722 & 0.01359 & 0.0282 & 0.0259 & 0.0112 & 0.0418 & 0.0345 & 0.0282 & 0.0436 & 0.0363 & 0.0291 \\
\hline$R^{2}$ & 0.9906 & 0.9845 & 0.9857 & 0.9947 & 0.9861 & 0.9731 & 0.9864 & 0.9794 & 0.9916 & 0.9824 & 0.9912 & 0.9902 \\
\hline
\end{tabular}

It was noted that the value of the rate constant $k_{2}$ decreases with increasing initial RB5 concentration (Table 4). With the increase in concentration, the trend becomes more obvious, but then levels of at approx. $110 \mathrm{mg} \mathrm{dm}^{-3}$. The explanation for this behavior can be the lower competition of the dye species for the sorp- 
tion surface sites at lower dye concentrations. Decreased sorption rates at higher concentrations result from the heightened competition for the surface active sites [22], except in the case of the formation of dye molecule aggregates, which reduces the effective concentration of the sorbate species in the solution.

Namely, dye ions tend do aggregate or to self-associate in aqueous solutions [37]. The almost complete formation of dimers occurs even at very low dye concentrations $\left(10^{-4}-10^{-6} \mathrm{M}\right)$ before subsequent aggregation takes place; it happens initially between dimeric units and then proceeds onto higher order aggregation [38]. Szyguła and associates established that the strongly acidic sulphonic groups reacted with the protonated amino groups of chitosan and that the dye removal was higher the greater the number of sulphonic groups in the dyes [27]. Their findings confirmed that in comparison with other sulphonic group-containing dyes, RB5 needed a lower number of amine functionalities for neutralizing sulphonic groups of the dye, in all probability as a result of dye aggregation.

Based on the PSO model the half-life of RB5 sorption by PGME-deta $\left(t_{1 / 2}\right)$ is inversely related to the product of the sorption capacity of the sorbent and PSO constant, i.e., the initial sorption rate [39]:

$$
t_{1 / 2}=\frac{1}{k_{2} Q_{e}}
$$

The $t_{1 / 2}$ gradually increased from $7 \mathrm{~min}$ for $c_{0}=30$ $\mathrm{mg} \mathrm{dm}{ }^{-3}$ to $35 \mathrm{~min}$ for $110 \mathrm{mg} \mathrm{dm}^{-3}$ and then decreased to $29 \mathrm{~min}$ for $130 \mathrm{mg} \mathrm{dm}^{-3}$ and $14 \mathrm{~min}$ for 150 $\mathrm{mg} \mathrm{dm} \mathrm{m}^{-3}$ (Table 4), possibly due to dye aggregation at higher concentrations as stated above.

Raising temperature also led to a significant increase in the initial sorption rate $(h)$ and considerable decrease in $t_{1 / 2}$, being the lowest $\left(5 \mathrm{~min}\right.$ ) for $50 \mathrm{mg} \mathrm{dm}^{-3}$ at $318 \mathrm{~K}$, which may indicate a kinetically controlled process. However, the sorption capacities at $180 \mathrm{~min}$ are nearly the same at 288 and $318 \mathrm{~K}$ for this concentration, implying the possible presence of other rategoverning processes (Table 5). It is furthermore noteworthy that for $90 \mathrm{mg} \mathrm{dm}^{-3}, t_{1 / 2}$ decreased from $33 \mathrm{~min}$ for $288 \mathrm{~K}$ to only $13 \mathrm{~min}$ at $318 \mathrm{~K}$.

The fitting of parameters of the sorption kinetic data to the PSO kinetic model allows exploration of the temperature effect on the values of the sorption rate constant $\left(k_{2}\right)$. The values for $R^{2}$ for RB5 removal by PGME-deta were $\geq 0.999$ indicating that the PSO model is appropriate for description of the effect of the solution temperature on the process kinetics (Table 5). This fact is an additional confirmation that chemisorption was the rate-limiting step, within the confines of the mass transfer in the sorption systems [40]. The $k_{2}$ values decreased with the decline in temperature and the half-life of the process was delayed for lower tem- peratures. This indicates that the RB5 surface sorption step is not the only rate-controlling in the sorption process and that the improvement in the rate of RB5 removal as the temperature increases may be due to the increased movement of the dye molecules as the solution temperature increases, which in turn enhances the RB5 diffusion from the bulk solution to the sorbent external and internal surface [41].

\section{Apparent activation energy of sorption}

The activation energy for the RB5/PGME-deta sorption system can be determined from the linearized Arrhenius equation:

$\ln k_{2}=\ln A-\frac{E_{\mathrm{a}}}{R T}$

where $A$ is the temperature independent factor (frequency factor) $\left(\mathrm{g} \mathrm{mmol}^{-1} \mathrm{~min}^{-1}\right), E_{\mathrm{a}}$ is the activation energy $\left(\mathrm{kJ} \mathrm{mol}^{-1}\right), T$ is the temperature $(\mathrm{K})$ and $R$ is the universal gas constant equal to $8.314 \mathrm{~J} \mathrm{~mol}^{-1} \mathrm{~K}^{-1}$. The $\ln k_{2}$ vs. $1 / T$ plot was observed to be linear with acceptable $R^{2}$ values for the investigated dye concentrations and $E_{\mathrm{a}}$ values for the studied sorption system were calculated from the slopes. These parameter's values may provide insights into the sorption mechanism. The calculated values of activation energy ranged from 28.3 to $39.2 \mathrm{~kJ} \mathrm{~mol}^{-1}$ for the investigated RB5 concentrations (50-90 $\mathrm{mg} \mathrm{dm}^{-3}$ ). These relatively small values of the activation energy (below $42 \mathrm{~kJ} \mathrm{~mol}^{-1}$ ) corroborate the fact that the process of RB5 removal by use of aminofunctionalized macroporous PGME is diffusion-controlled, i.e., the chemical step is faster in comparison with the mass transfer of RB5 molecules the inside the copolymer pores [42].

\section{Particle diffusion-based models}

Recognizing the mechanism of sorption, that is, the reaction at the surface (physical or chemical) as well as the rate controlling mechanism is significant. Generally, when microporous/mesoporous/macroporous sorbents are used, the rate controlling mechanism is strongly dependent on either pore or surface diffusion [9]. In order to determine whether the process rate in the studied sorption system is directed by film or pore diffusion, the intraparticle and Mckay's models were applied:

A classical approach to examine the influence of intraparticle diffusion is plotting the equation $[29,43]$ :

$$
Q_{t}=k_{\mathrm{id}} t^{1 / 2}+c_{\mathrm{id}}
$$

where $k_{\text {id }}$ is the intraparticle diffusion coefficient $\left(\mathrm{mg} \mathrm{g}^{-1}\right.$ $\left.\min ^{-0.5}\right)$, and $c_{\text {id }}$ is a constant.

In the case of a linear $Q_{t} v s . t^{1 / 2}$ plot, and if the line passes through the origin, intraparticle diffusion is the 
only rate-controlling step [33]. If not, some other mechanisms are also involved.

Weber and Morris model [43] allows interpretation of intraparticle diffusion (IPD) in 3 different forms [44]: 1) $Q_{t}$ is plotted against $t^{1 / 2}$ to obtain a straight line that is forced to pass through the origin [45]; 2) multi-linearity in $Q_{t}$ vs. $t^{1 / 2}$ plot is taken into account (i.e., 2 or 3 steps are included to follow the whole process) [46]; and 3) $Q_{t}$ is plotted against $t^{1 / 2}$ to get a straight line but does not automatically pass through the origin; i.e., there is an intercept [47]. In the literature, virtually all the described intercepts are positive, implying that rapid sorption takes place within a short period of time [44].

The first method was used to process the collected data in this study. The plot of the square root of time $\left(t^{1 / 2}\right)$ vs. the uptake $\left(Q_{t}\right)$ for the RB5 sorption (Figure 5) resulted in a linear relationship, implying that one of the rate-limiting steps of sorption may be intraparticle diffusion.

There are opinions in the literature that multi-linear $Q-t^{1 / 2}$ plots might be the consequence of the distinctive phases in intraparticle diffusion. Assorted studies considering sorbents with extensive pore size distribution demonstrated that multi-linear plots might represent the stages of intraparticle diffusion into the macro-, meso- and microporous structure of sorbent $[48,49]$. The first phase could be assigned to the sorption over the outer surface and in the macropores of polymeric sorbents, rendering it the fastest sorption stage. The second stage could be attributed to the intraparticle diffusion through mesopores, while the third could be regarded as the diffusion through micropores, and, of course, it is followed by the establishment of equilibrium. The third stage might be omitted or combined with the equilibrium attainment phase, if the sorbent in question is macroporous, as is the case with PGME-deta.

The sufficient macro- and mesopores of PGME-deta provided the effective diffusion channels for RB5 to sorption sites and enhanced the sorption kinetics. The diffusion resistance of sorbate in mesopores should be larger than in macropores.

From Figure 5 it can be appreciated that RB5 sorption tends to follow the following stages. The intraparticle diffusion model suggests that the film diffusion (stage 1) is absent from the plot due to completing before $10 \mathrm{~min}$ (the first recorded point), and that the final equilibrium sorption (stage 3) started after 120 to $180 \mathrm{~min}$. The linear portion(s) included the intermediate sorption period, representing intraparticle diffusion and binding of RB5 by active sites in PGME-deta particles.

The intraparticle rate constants at different initial concentrations acquired from the slope of the plots were summarized in Table 4. Higher initial concentration gave larger slope. A number of investigations reported previously the variation of intraparticle diffusion rate constant as a normal phenomenon [44] due to the change in diffusion driving force which is strongly dependent on the availability of sorbate per unit mass of the sorbent [50]. High initial $k_{i}$ values may be attributable to a large number of vacant sites available at the early stage with respect to initial dye concentrations, resulting in an increased concentration gradient between sorbate in solution and sorbate on the sorbent surface. Later on this concentration gradient diminishes due to accumulation of dye particles in the vacant sites, leading to a decrease in sorption rate.

The last portion (after 120-180 min, depending on the initial concentration and temperature, not shown

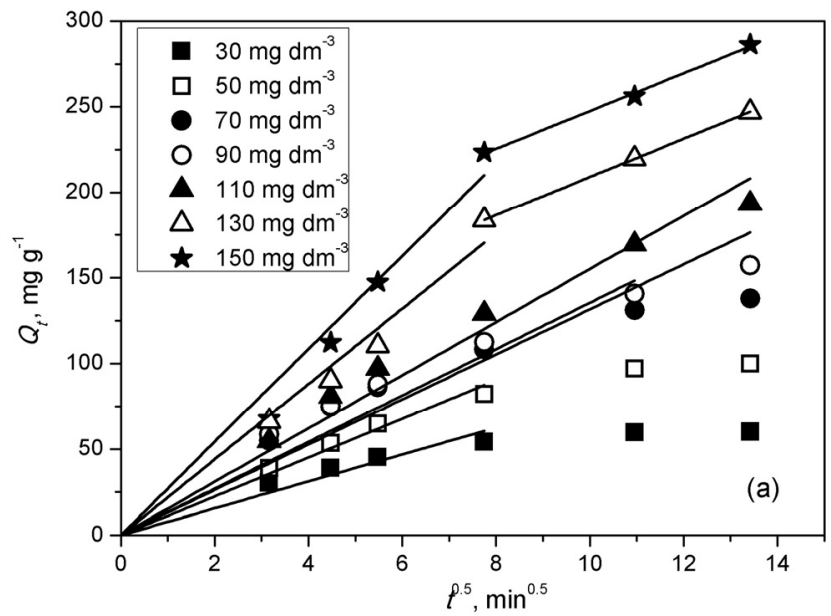

(a)

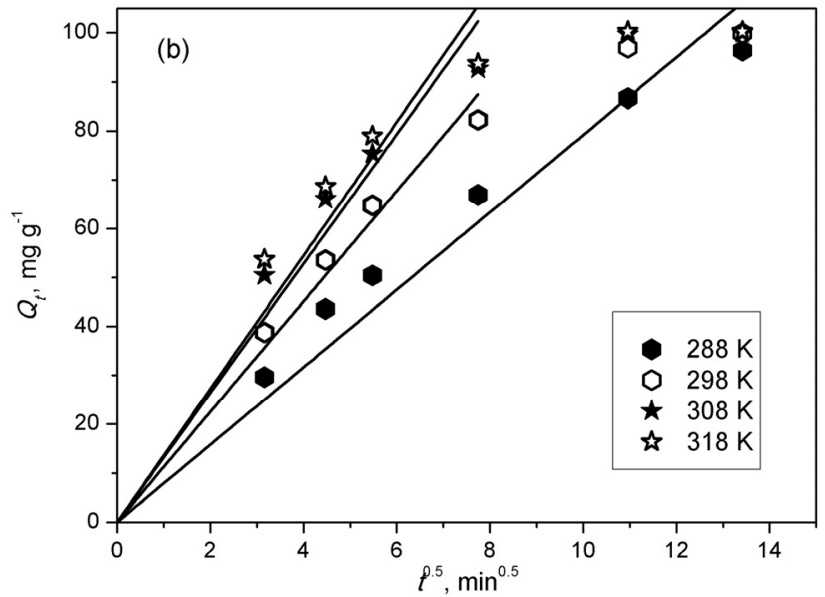

(b)

Figure 5. a) Plot of intraparticle diffusion model for sorption of RB5 on PGME-deta for different initial concentrations $\left(30 \mathrm{mg} \mathrm{dm}^{-3}\right.$ black squares; $50 \mathrm{mg} \mathrm{dm}^{-3}$ - white squares; $70 \mathrm{mg} \mathrm{dm}^{-3}$ - black circles; $90 \mathrm{mg} \mathrm{dm}^{-3}$ - white circles; $110 \mathrm{mg} \mathrm{dm}^{-3}$ - black triangles; $130 \mathrm{mg} \mathrm{dm}$ - white triangles; $150 \mathrm{mg} \mathrm{dm}$ - black stars) and b) temperatures for $50 \mathrm{mg} \mathrm{dm}^{-3}$ (288 $\mathrm{K}$ - black hexagons; $298 \mathrm{~K}-$ white hexagons; $308 \mathrm{~K}$-black stars; $318 \mathrm{~K}$-white stars). 
in Figure 5) is the final equilibrium stage where the intraparticle diffusion in micropores begins to decalerate due to the extremely low solute concentration in solution [49]. The calculated $R^{2}$ values were high; thus it could be deduced that intraparticle diffusion seemed to be the most significant rate process controlling sorption of RB5 on PGME-deta.

If the external resistance to mass transfer surrounding the particles is dismissed, as has been proposed for other sorbate/sorbent systems [51], the single plotted line will depict macropore and mesopore diffusion for concentrations $30-110 \mathrm{mg} \mathrm{dm}^{-3}$ (10-180 $\left.\mathrm{min}\right)$; in the case of two discernible slopes (130 and $150 \mathrm{mg} \mathrm{dm}^{-3}$ ), the first one will correspond to macropore and the second to mesopore diffusion. The equilibrium is achieved probably through micropore diffusion. For the two above mentioned concentrations, the results showed that the diffusion rates decreased with increasing the contact time. Over time, the pores for diffusion become smaller, because the molecules of the dye diffuse into the inner structure of the sorbents, causing the decrease of the free path for the molecules in the pore as well as pore blockage [9].

Cumulative pore distribution curve for PGME-deta determined by mercury porosimetry is presented in Figure 6 . In the case of PGME-deta only two sections are discernible for high initial concentrations (130 and $150 \mathrm{mg} \mathrm{dm}^{-3}$ ), since there are almost no micropores present in the sample; the fraction surface area of pores $7.5-50 \mathrm{~nm}$ in diameter is $46 \%$ and from $50-10000$ $\mathrm{nm}$ is $54 \%$. The fractional uptake of RB5 in the first linear region (macropore) is roughly $43 \%$, and in the second linear region (mesopores) (53\%). The remaining $4 \%$ can most likely be ascribed to the pores less than $7.5 \mathrm{~nm}$ in diameter which are not measurable by mercury porosimetry. Also, it needs to be taken into account that the cut-off value between macropore and mesopore diameter is merely arbitrary and does not reflect the pore size distribution shown in Figure 6.

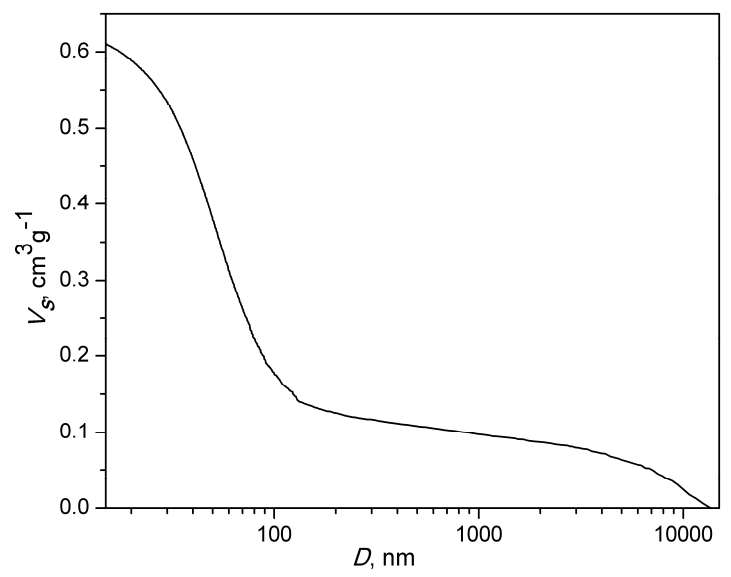

Figure 6 Cumulative pore size distribution curve for sample PGME-deta.
$\mathrm{Li}$ and associates determined that the sorption of solute molecules can happen in pore diameters of 1.3-1.8 times the solute molecular width [52]. If a value of 1.6 times the molecular width is presumed, this implies a minimum pore sorbing diameter of $1.37 \mathrm{~nm}$ for RB5 as illustrated by Ip and associates [9]. In the case of PGME-deta this threshold value is amply surpassed, seeing that the average pore diameter is $50 \mathrm{~nm}$ (Table 1). The specific surface area of PGME-deta is quite low (53 $\mathrm{m}^{2} / \mathrm{g}$, Table 1) in comparison with, e.g., active charcole and zeolites. At lower concentrations, the effect of pore distribution is not pronounced enough to yield two slopes, since the available dye is well below the concentration that instigates aggregation of dye molecules. The findings of Caceres et al. supported the supposition that this result may be due to the magnitude of the sorbent surface area [51].

Further substantiation of the above remark was executed with the help of Mckay's graph based on the equation $[53,54]$ :

$\log (1-F)=-\left(\frac{S}{2.303}\right) t$

where $F$ is the fractional attainment of equilibrium at time $t(\mathrm{~min})$ and $S$ is the rate parameter [53].

Figure 7 displays typical Mckay's plots at different RB5 concentration and at different temperatures. The $\log (1-F)$ vs. $t$ plots were linear $\left(R^{2} \geq 0.97\right)$. The $S$ values calculated from their slopes and the intercepts are presented in Tables 4 and 5. It is remarkable that the linearity is maintained in the whole range of the time axis with intercepts close to 0 for most of the plots and thus can be deduced that the sorption rate of RB5 on PGME-deta is governed mainly by internal transport mechanism, i.e., pore diffusion, with minor influence of film diffusion. Both processes were enhanced with the increase of initial concentration and temperature.

\section{Sorption isotherms}

Equilibrium sorption data were fitted into Freundlich and Langmuir equations in order to determine model that is most appropriate to describe obtained results.

The linear form of the Freundlich equation [55] is as follows:

$\ln Q_{\mathrm{e}}=\ln K_{\mathrm{F}}+\frac{1}{n} \ln c_{\mathrm{e}}$

Where $c_{\mathrm{e}}$ is the equilibrium dye concentration in solution $\left(\mathrm{mg} \mathrm{dm}{ }^{-3}\right)$, while $\left.K_{\mathrm{F}}\left(\mathrm{mg} \mathrm{g}^{-1}\right) /\left(\mathrm{mg} \mathrm{dm}^{-3}\right)^{1 / n}\right)$ and $n$ are the Freundlich sorption constants characteristic for the system.

The well-known linearized expression of the Langmuir model is $[56,57]$ : 

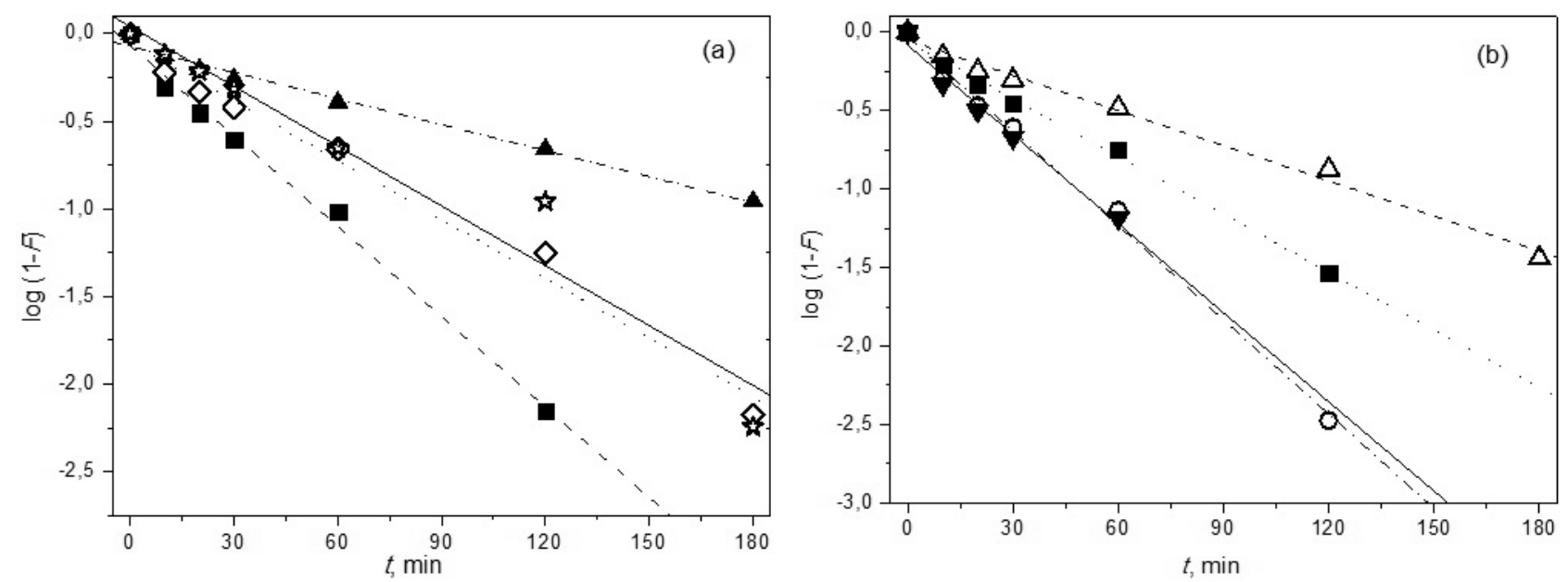

Figure 7. a) Mckay plots for RB5 sorption by PGME-deta at selected initial concentrations ( $30 \mathrm{mg} \mathrm{dm}^{-3}$ - black squares; $70 \mathrm{mg} \mathrm{dm} \mathrm{m}^{-3}$ - white rhombi; $110 \mathrm{mg} \mathrm{dm^{-3 }}$ - black triangles; $150 \mathrm{mg} \mathrm{dm}^{-3}$ - white star) and b) at different temperatures (288 $\mathrm{K}$ - white triangles; $298 \mathrm{~K}$-black squares; $308 \mathrm{~K}$ - white circles; $318 \mathrm{~K}$-black triangles).

$\frac{c_{\mathrm{e}}}{Q_{\mathrm{e}}}=\frac{1}{Q_{\max } K_{\mathrm{L}}}+\frac{c_{\mathrm{e}}}{Q_{\max }}$

where $Q_{\max }$ is the monolayer capacity of the sorbent $\left(\mathrm{mg} \mathrm{g}^{-1}\right)$ and $K_{\mathrm{L}}$ is the Langmuir sorption constant $\left(\mathrm{dm}^{3}\right.$ $\left.\mathrm{g}^{-1}\right)$.

The characteristics of Langmuir isotherm can be expressed by dimensionless constant called Langmuir equilibrium parameter $R_{L}$ given in Eq. 4 [57]:

$$
R_{\mathrm{L}}=\frac{1}{1+K_{\mathrm{L}} c_{0}}
$$

The value of $R_{\mathrm{L}}$ indicates the type of the isotherm either to be unfavorable $\left(R_{\mathrm{L}}>1\right)$, linear $\left(R_{\mathrm{L}}=1\right)$, favorable $\left(0<R_{\mathrm{L}}<1\right)$ or irreversible $\left(R_{\mathrm{L}}=0\right)$.

Table 6. Langmuir and Freundlich constants for RB5 sorption by PGME-deta

\begin{tabular}{llc}
\hline Model & \multicolumn{1}{c}{ Parameter } & Value \\
\hline Langmuir & $Q_{\max } / \mathrm{mg} \mathrm{g}^{-1}$ & 353 \\
& $K_{\mathrm{L}} / \mathrm{dm}^{3} \mathrm{~g}^{-1}$ & 2317 \\
& $R_{L} \times 10^{4}$ & 2.88 \\
& $R^{2}$ & 0.9999 \\
Freundlich & $n$ & 21.0 \\
& $1 / n$ & 0.048 \\
& $K_{-} / \mathrm{mg} \mathrm{g}^{-1} /\left(\mathrm{mg} \mathrm{dm}^{-3}\right)^{1 / n}$ & 262.2 \\
& $R^{2}$ & 0.6301 \\
\hline
\end{tabular}

When the quantity of protonated amine groups was sufficient to completely neutralize the anionic charges on RB5, the removal of this dye reached a maximum [40].

According to the results for coefficients of determination presented in Table 6 , Freundlich model is inapplicable in this case due to the very low $R^{2}$ value.
This value for Langmuir model is very close to unity and therefore correct for this system. At the same time, the value of $R_{\mathrm{L}}=2.88 \times 10^{-4}$ designates that this sorption process of RB5 by PGME-deta lies well within the favorable limits, and close to the irreverisible. The fact that the Langmuir isotherm fits the experimental data more appropriately indicates that the distribution of active sites by PGME-deta is homogeneous and that RB5 is sorbed as a monolayer.

\section{Comparison with other sorbents}

The literature data on RB5 removal includes a variety of sorbents, some of them were listed in Table 7. However, diverse experimental conditions make direct comparison of the literature data difficult to achieve. Nevertheless, some of the results will be discussed.

The maximum sorption capacity, $Q_{\max }$ (experimental or Langmuir) has been extensively taken as an indicator of the efficiency of a sorbent. The maximum RB5 sorption capacities of various sorbents lie in a wide range between $793 \mathrm{mg} \mathrm{g}^{-1}$ reported for high lime fly ash [11] up to approximately $774 \mathrm{mg} \mathrm{g}^{-1}$ for chitosan with amino and quaternary ammonium chloride groups [12].

The maximum sorption capacity calculated from the Langmuir isotherm equation for sorption of RB5 on PGME-deta was $353 \mathrm{mg} \mathrm{g}^{-1}$ (Table 7). The maximum sorption capacities of analogous copolymers are as follows: $34.2 \mathrm{mg} \mathrm{g}^{-1}$ for chitosan [58], $201.90 \mathrm{mg} \mathrm{g}^{-1}$ for chitosan hydrogel beads formed by alkali gelation (CB) [13], $168.07 \mathrm{mg} \mathrm{g}^{-1}$ for chitosan hydrogel beads formed by sodium dodecyl sulphate gelation (CSB) [13], $625 \mathrm{mg}$ $\mathrm{g}^{-1}$ for chitosan/amino resin [12] and $484 \mathrm{mg} \mathrm{g}^{-1}$ for glycidyl methacrylate/methelenebisacrylimide resin loaded with tetraethelenepentamine (GMA/MBA-TEPA) [3]. For all materials listed in the previous sentence, the Langmuir model was the best fit for the equilibrium data, and the kinetic data was best represented by the 
Table 7. Overview of RB5 uptake with various adsorbents; $L-F=$ Langmuir-Freundlich; $R-P=$ Redlich-Peterson isotherm model

\begin{tabular}{|c|c|c|c|c|c|c|c|c|}
\hline Sorbent & $\mathrm{pH}$ & $T / \mathrm{K}$ & $c_{\mathrm{i}}$ range, $\mathrm{mg} \mathrm{L}^{-1}$ & $c_{\mathrm{i}} / \mathrm{mg} \mathrm{L}^{-1}$ & Isotherm model & Kinetic model & $Q_{\max } / \mathrm{mg} \mathrm{g}^{-1}$ & Ref. \\
\hline Bone char & 5.2 & 298 & $50-200$ & - & $\mathrm{L}-\mathrm{F}$ & Pseudo-second & 160 & [9] \\
\hline${ }^{\mathrm{a}} \mathrm{F} 400$ & 5.2 & 298 & $50-200$ & - & $\mathrm{L}-\mathrm{F}$ & Pseudo-second & 198 & [9] \\
\hline${ }^{\mathrm{a}} \mathrm{BACX} 2$ & 5.2 & 298 & $50-200$ & - & $\mathrm{R}-\mathrm{P}$ & Pseudo-second & 286 & [9] \\
\hline aACX6 & 5.2 & 298 & $50-200$ & - & $\mathrm{R}-\mathrm{P}$ & Pseudo-second & 473 & [9] \\
\hline Beet pulp carbon (BPC) & 1.0 & 298 & $20-500$ & 400 & $\mathrm{~L}$ & Pseudo-second & 80 & [10] \\
\hline High lime fly ash & 5.64 & 293 & $0-30$ & 27 & $\mathrm{~F}$ & Pseudo-second & 7.93 & [11] \\
\hline Chitosan & 4.0 & 306 & $45-100$ & 35 & $\mathrm{~L}$ & Pseudo-second & 34.2 & [58] \\
\hline${ }^{\mathrm{b}} \mathrm{CB}$ & 6.0 & 303 & $0-1000$ & 900 & L & Pseudo-first & 201.90 & [13] \\
\hline${ }^{\mathrm{b}} \mathrm{CSB}$ & 6.0 & 303 & $0-1000$ & 900 & $\mathrm{~L}$ & Pseudo-first & 168.07 & [13] \\
\hline${ }^{\mathrm{b}} \mathrm{PEI}-\mathrm{CB}$ & 3.0 & 298 & $5-100$ & 2000 & $\mathrm{~L}$ & Pseudo-first & 709.27 & [13] \\
\hline${ }^{\mathrm{b}} \mathrm{PEI}-\mathrm{CSB}$ & 3.0 & 293 & $32-225$ & 3000 & L & Pseudo-first & 413.23 & [13] \\
\hline Chitosan/amino resin & 3.0 & 298 & $0-400$ & 400 & L & Pseudo-second & 625 & [12] \\
\hline $\begin{array}{l}\text { Chitosan with amino and } \\
\text { quaternary ammonium } \\
\text { chloride groups }\end{array}$ & 3.0 & 298 & $0-200$ & 200 & L & Pseudo-second & 774 & [12] \\
\hline 'GMA/MBA-TEPA & 3.0 & 298 & 600 & 500 & L & Pseudo-second & 484 & [3] \\
\hline
\end{tabular}

${ }^{a_{F} 400 ~-~ c o m m e r c i a l ~ a c t i v e ~ c a r b o n ~ a n d ~ b a m b o o ~ d e r i v e d ~ c a r b o n s, ~ B A C X 2 ~ a n d ~ B A C X 6 ~ w i t h ~ a ~ h i g h ~ s p e c i f i c ~ s u r f a c e ~ a r e a s, ~ i . e ., ~} 2123$ and 1400 m ${ }^{2} / g$, respectively; ${ }^{b} \mathrm{CB}$ - chitosan hydrogel beads formed by alkali gelation, CSB - chitosan hydrogel beads formed by sodium dodecyl sulphate (SDS) gelation, PEI-CB - polyethyleneimine (PEI)-grafted CB; PEI-grafted CSB (PEI-CSB); ' GMA/MBA-TEPA - glycidyl methacrylate/methelenebisacrylimide resin loaded with tetraethelenepentamine

pseudo-second-order model with the exception of $\mathrm{CB}$ and CSB where the pseudo-first-order model provided the most adequate representation. For GMA/MBA-TEPA [3], chitosan/amino resin [12] and CB and CSB [13] it was also shown that the intraparticle diffusion may play a significant role in those sorption systems.

\section{CONCLUSION}

Removal of textile dye Reactive Black 5 (RB5) from aqueous solutions was studied using macroporous crosslinked glycidyl methacrylate based copolymer additionally functionalized with diethylene triamine (PGME-deta). The capacity of PGME-deta for RB5 sorption was tested with respect to $\mathrm{pH}$, sorbent dosage, contact time and initial concentration. The functionalized sample showed affinity for RB5 sorption due to the presence of protonated amino groups that attract anionic sulfonate groups in the dye molecule and the possibility of hydrogen bonds formation between the sorbent and the sorbate. The sorption is $\mathrm{pH}$ sensitive having maximum at $\mathrm{pH} 2$ and decreasing with the increase of $\mathrm{pH}$. A very high maximum dye sorption removal of $85 \%$ was observed at $\mathrm{pH} 2$, while only $24 \%$ of dye was removed at $\mathrm{pH} 11$ after $60 \mathrm{~min}$. Sorption kinetics study demonstrated that the sorption of RB5 by PGME-deta obeyed the PSO kinetic model, suggesting that the sorption rate is controlled by both sorbent capacity and sorbate concentration. The process mechanism dominantly consisted of intraparticle diffusion, with minor involvement of film diffusion.
These diffusion mechanisms were more prevalent with the decrease in temperature and the increase in concentration. The isotherm data was best fitted with the Langmuir model, indicating homogeneous distribution of active sites on the PGME-deta and monolayer sorption. The calculated sorption rates improved with increasing temperature and an activation energy close to $40 \mathrm{~kJ} \mathrm{~mol}^{-1}$ was determined, suggesting that chemisorption was also rate-controlling.

\section{Abbreviations}

\begin{tabular}{|c|c|}
\hline$A$ & $\begin{array}{l}\text { Temperature independent factor } \\
\text { (frequency factor) }\left(\mathrm{g} \mathrm{mmol}^{-1} \mathrm{~min}^{-1} \text { ) }\right.\end{array}$ \\
\hline$c_{\mathrm{e}}$ & $\begin{array}{l}\text { Equilibrium dye concentration in solution } \\
\left(\mathrm{mg} \mathrm{dm}^{-3}\right)\end{array}$ \\
\hline$c_{0}$ & Initial dye concentration \\
\hline$c_{\mathrm{id}}$ & $\begin{array}{l}\text { Constant in intraparticle diffusion model } \\
\text { (intercept) }\end{array}$ \\
\hline$c_{t}$ & $\begin{array}{l}\text { Dye solution concentrations }\left(\mathrm{mg} \mathrm{dm}^{-3}\right) \\
\text { after sorption time } t\end{array}$ \\
\hline$D_{\mathrm{av}}$ & Average pore diameter $(\mathrm{nm})$ \\
\hline$D_{V / 2}$ & $\begin{array}{l}\text { Pore diameter which corresponds to half of } \\
\text { pore volume }\end{array}$ \\
\hline$E_{\mathrm{a}}$ & Activation energy $\left(\mathrm{kJ} \mathrm{mol}^{-1}\right)$ \\
\hline$F$ & $\begin{array}{l}\text { Fractional attainment of equilibrium at } \\
\text { time } t \text { (min) }\end{array}$ \\
\hline$h$ & $\begin{array}{l}\text { Initial sorption rate from PSO model (mg g } \\
{ }^{1} \mathrm{~min}^{-1} \text { ) }\end{array}$ \\
\hline$k_{1}$ & PFO rate constant $\left(\mathrm{min}^{-1}\right)$ \\
\hline$k_{2}$ & PSO rate constant $\left(\mathrm{g} \mathrm{mg}^{-1} \mathrm{~min}^{-1}\right)$ \\
\hline
\end{tabular}




$$
\begin{aligned}
& K_{\mathrm{F}} \quad \text { Freundlich sorption constant characteristic } \\
& \text { for the system } \\
& k_{\text {id }} \quad \text { Intraparticle diffusion coefficient }\left(\mathrm{mg} \mathrm{g}^{-1}\right. \\
& \left.K_{\mathrm{L}} \quad \min ^{-0.5}\right) \\
& m \quad \text { Amount of the copolymer beads used for } \\
& \text { the experiment (in g) } \\
& n \quad \text { Freundlich sorption constant characteristic } \\
& \text { for the system } \\
& \text { PFO Pseudo-first kinetic model (PFO) } \\
& \text { PGME Glycidyl methacrylate and ethylene glycol } \\
& \text { dimethacrylate copolymer }
\end{aligned}
$$

PGME-deta Glycidyl methacrylate and ethylene glycol dimethacrylate copolymer functionalized with diethylene triamine

$\mathrm{pH}_{\mathrm{PZC}} \quad$ Value of $\mathrm{pH}$ when the overall charge on the sorbent surface is zero

PSO Pseudo-second-order (PSO) kinetic model

$Q_{e} \quad$ Amount of sorbed dye at equilibrium (mg $\left.\mathrm{g}^{-1}\right)$

$Q_{e}{ }^{\text {cal }} \quad$ Amount of sorbed dye at equilibrium calculated from PSO $\left(\mathrm{mg} \mathrm{g}^{-1}\right)$

$Q_{\max } \quad$ Maximum sorption capacity $\left(\mathrm{mg} \mathrm{g}^{-1}\right)$

$Q_{60} \quad$ Sorption capacity after 60 minutes $\left(\mathrm{mg} \mathrm{g}^{-1}\right)$

$Q_{t} \quad$ Amount of dye sorbed by the sorbent at time $t\left(\mathrm{mg} \mathrm{g}^{-1}\right)$

$R^{2} \quad$ Determination coefficient

RB5 Reactive Black 5

$R_{\mathrm{g}} \quad$ Universal gas constant equal to $8.314 \mathrm{~J}$ $\mathrm{mol}^{-1} \mathrm{~K}^{-1}$

$R_{\mathrm{L}} \quad$ Dimensionless constant called Langmuir equilibrium parameter

$S \quad$ Rate parameter

$S_{\mathrm{s}, \mathrm{Hg}} \quad$ Specific surface area $\left(\mathrm{m}^{2} \mathrm{~g}^{-1}\right)$

$T$ Temperature (K)

$t_{1 / 2} \quad$ Sorption half-time; i.e. time required to reach $50 \%$ of the total sorption capacity

$V \quad$ Volume of the aqueous phase $\left(\mathrm{dm}^{3}\right)$

$V_{s} \quad$ Specific pore volume $\left(\mathrm{cm}^{3} \mathrm{~g}^{-1}\right)$

\section{Acknowledgements}

This work was supported by the Ministry of Education, Science and Technological Development of the Republic of Serbia (Projects III 43009, TR 37021 and III 45001).

\section{REFERENCES}

[1] A.E. Ofomaja, Kinetic study and sorption mechanism of methylene blue and methyl violet onto mansonia (Mansonia altissima) wood sawdust, Chem. Eng. J. 143 (2008) 85-95.

[2] J.J. Pierce, Colour in textile effluents - the origins of problem, J. Soc. Dyers Colour. 110 (2008) 131-133.

[3] K.Z. Elwakeel, M. Rekaby, Efficient removal of Reactive Black 5 from aqueous media using glycidyl methacrylate resin modified with tetraethelenepentamine, J. Hazard. Mater. 188 (2011) 10-18.

[4] M.A. Brown, S.C. De Uito Predicting azo dye toxicity, Crit. Rev. Env. Sci. Technol. 23 (1993) 249-324.

[5] A. Kuleyin, F. Aydin, Removal of reactive textile dyes dyes (Remazol Brillant Blue R and Remazol Yellow) by surfactant-modified natural zeolite, Environ. Prog. Sustainable Energy 30 (2011) 141-151.

[6] [6] T. Robinson, G. McMullan, R. Marchant, P. Nigam, Remediation of dyes in textile eluent: a critical review on current treatment technologies with a proposed alternative, Bioresour. Technol. 77 (2001) 247-255

[7] Y.M. Slokar, A.M. Le Marechal, Methods of decoloration of textile wastewaters, Dyes Pigments 37 (1997) 335$-356$.

[8] M.N.V.R. Kumar, T.R. Sridhari, K.D. Bhavani, P.K. Dutta, Trends in colour removal from textile mill effluents, Colorage 40 (1998) 25-34.

[9] A.W.M. Ip, J.P. Barford, G. McKay, A comparative study on the kinetics and mechanisms of removal of Reactive Black 5 by adsorption onto activated carbons and bone char, Chem. Eng. J. 157 (2010) 434-442.

[10] A.Y. Dursun, O. Tepe, G. Uslu, G. Dursun, Y. Saatci, Kinetics of Remazol Black B adsorption onto carbon prepared from sugar beet pulp, Environ. Sci. Pollut. Res. Int. 20 (2013) 2472-2483.

[11] Z. Eren, F.N. Acar, Equilibrium and kinetic mechanism for Reactive Black 5 sorption onto high lime Soma fly ash, J. Hazard. Mater. 143 (2007) 226-232.

[12] K.Z. Elwakeel, Removal of Reactive Black 5 from aqueous solutions using magnetic chitosan resins, J. Hazard. Mater. 167 (2009) 383-392.

[13] S. Chatterjee, T. Chatterjee, S.H. Woo, Influence of the polyethyleneimine grafting on the adsorption capacity of chitosan beads for Reactive Black 5 from aqueous solutions, Chem. Eng. J. 166 (2011) 168-175.

[14] Q. Liu, L. Wang, A. Xiao, J. Gao, W. Ding, H. Yu, J. Huo, M. Ericson, Templated preparation of porous magnetic microspheres and their application in removal of cationic dyes from wastewater, J. Hazard. Mater. 181 (2010) 586-592.

[15] S. Jovanović, A. Nastasović, N. Jovanović, K. Jeremić, Z. Savić, The influence of inert component composition on the porous structure of glycidyl methacrylate/ethylene glycol dimetacrylate copolymers, Angew. Makromol. Chem. 219 (1994)161-168.

[16] A. Nastasović, D. Jakovljević, Z. Sandić, D. Đorđević, Lj, Malović, S. Kljajević, J. Marković, A. Onjia, in: M.I. Barroso (Ed.), Reactive and Functional Polymers Research Advances, Nova Science Publishers, New York, 2008, pp. 79-112.

[17] R.V. Hercigonja, D.D. Maksin, A.B. Nastasović, S.S. Trifunović, P.B. Glodić, A.E. Onjia, Adsorptive removal of technetium-99 using macroporous poly(GMA-coEGDMA) modified with diethylene triamine, J. Appl. Polym. Sci. 123 (2012) 1273-1282.

[18] Z. Sandić, A. Nastasović, N. Jović-Jovičić, A. MilutinovićNikolić, D.J. Jovanović, Sorption of textile dye from 
aqueous solution by macroporous amino functionalized copolymer. J. Appl. Polym. Sci. 121 (2011) 234-242.

[19] G. Bayramoglu, M.Y. Arica, Removal of reactive dyes from wastewater by acrylate polymer beads bearing amino groups: Isotherm and kinetic studies, Color. Technol. 129 (2013) 114-124.

[20] G.M. Kline, Analytical Chemistry of Polymers, Interscience, New York, 1959.

[21] B.H. Hameed, I.A.W. Tan, A.L. Ahmad, Adsorption isotherm, kinetic modeling and mechanism of 2,4,6trichlorophenol on coconut husk-based activated carbon, Chem. Eng. J. 144 (2008) 235-244.

[22] H. Chen, G. Dai, J. Zhao, A. Zhong, J. Wu, H. Yan, Removal of copper(II) ions by a biosorbent-Cinnamomum camphora leaves powder, J. Hazard. Mater. 177 (2010) 228-236.

[23] S. Jovanović, A. Nastasović, N. Jovanović, K. Jeremić, Targeted porous structure of macroporous copolymers based on glycidyl methacrylate, Mater. Sci. Forum 214 (1996) 155-162.

[24] Lj. Malović, A. Nastasović, Z. Sandić, J. Marković, D. Đorđević, Z. Vuković, Surface modification of macroporous glycidyl methacrylate based copolymers for selective sorption of heavy metals, J. Mater. Sci. 42 (2007) 3326-3337.

[25] P.A. Webb, C. Orr, Analytical Methods in Fine Particle Technology. Micromeritics Instrument Corporation, Norcross, GA, 1997.

[26] V. Ponnusami, S. Vikram, S.N. Srivastava, Guava (Psidium guajava) leaf powder: novel adsorbent for removal of methylene blue from aqueous solutions, J. Hazard. Mater. 152 (2008) 276-286.

[27] A. Szyguła, E. Guibal, M. Ruiz, A.M. Sastre, The removal of sulphonated azo-dyes by coagulation with chitosan, Colloids Surfaces, A 330 (2008) 219-226.

[28] B. Royer, N.F. Cardoso, E.C. Lima, T.R. Macedo, C. Airoldi, A useful organofunctionalized layered silicate for textile dye removal, J. Hazard. Mater .181 (2010) 366-374 .

[29] A.S. Özcan, A. Özcan, Adsorption of acid dyes from aqueous solutions onto acid-activated bentonite, J. Colloid Interf. Sci. 276 (2004)39-46.

[30] C. Liu, Study of polyamines-functionalized PGMA beads as adsorbents for the removal of heavy metal ions from aqueous solutions, PhD. Thesis, National university of Singapore, Singapore, 2009.

[31] B. Oram, The pH of water, Water Research Center, http://www.water-research.net/ph.htm (accessed Dec, 2011).

[32] V.O. Arief, K. Trilestari, J. Sunarso, N. Indraswati, S. Ismadji, Recent progress on biosorption of heavy metals from liquid using low cost biosorbents: Characterization, biosorption parameters and mechanism studies, CleanSoil Air Water 36 (2008) 937-962

[33] P.K. Malik, Use of activated carbons prepared from sawdust and rice-husk for adsorption of acid dyes: A case study of Acid Yellow 36, Dyes Pigments 56 (2003) 239-249.
[34] S. Lagergren About the theory of so-called adsorption of soluble substances, K Sven. Vetenskapsakad Handl. 24 (1898) 1-39.

[35] Y.S. Ho, Review of second-order models for adsorption systems, J. Hazard. Mater., B 136 (2006) 681-689.

[36] K.J. Laidler, The World of Physical Chemistry, Oxford University Press Inc., New York, 1993.

[37] E. Coates, Aggregation of dyes in aqueous solutions, J. Soc. Dyers Colour. 85 (1969) 355-368.

[38] G.M. Walker, L.R. Weatherley, Adsorption of dyes from aqueous solution-the effect of adsorbent pore size distribution and dye aggregation, Chem. Eng. J. 83 (2001) 201-206.

[39] A.E. Ofomaja, E.B. Naidoo, Biosorption of copper from aqueous solution by chemically activated pine cone: $A$ kinetic study, Chem. Eng. J. 175 (2011) 260-270.

[40] M. Emine, Ni (II) removal from aqueous solutions using cone biomass of Thuja orientalis, J. Hazard. Mater. 137 (2006) 899-908.

[41] V.J. Inglezakis, M.D. Loizidou, H.P. Grigoropoulou, Ion exchange studies on natural and modified zeolites and the concept of exchange site accessibility, J. Colloid Interface Sci. 275 (2004) 570-576.

[42] G.S. Kirk, L.S. Donald, Temperature effect on nickel sorption kinetics at the mineral-water interface, Soil Sci. Soc. Am. J. 65 (2001) 719-728.

[43] W.J. Weber, Jr., J.C. Morris, Kinetics of adsorption on carbon from solution, J. Sanit. Eng. Div. Am. Soc. Civ. Eng. 89 (1963) 31-59.

[44] F.C. Wu, R.L. Tseng, R.S. Juang, Initial behavior of intraparticle diffusion model used in the description of adsorption kinetics, Chem. Eng. J. 153 (2009) 1-8.

[45] W. Zhang, Z. Xu, B. Pan, L. Lu, Q. Zhang, Q. Zhang, W. Du, B. Pan, Q. Zhang, Assessment on the removal of dimethyl phthalate from aqueous phase using a hydrophilic hypercrosslinked polymer resin NDA-702, J. Colloid Interface Sci. 311 (2007) 382-390.

[46] N. Dizge, C. Aydiner, E. Demirbas, M. Kobya, S. Kara, Adsorption of reactive dyes from aqueous solutions by fly ash: kinetic and equilibrium studies, J. Hazard. Mater. 150 (2008) 737-746.

[47] R. Dhodapkar, N.N. Rao, S.P. Pande, T. Nandy, S. Devotta, Adsorption of cationic dyes on Jalshakti, super absorbent polymer and photocatalytic regeneration of the adsorbent, React. Funct. Polym. 67 (2007) 540-548.

[48] C. Long, A. Li, H. Wub, Q. Zhang, Adsorption of naphthalene onto macroporous and hypercrosslinked polymeric adsorbent: Effect of pore structure of adsorbents on thermodynamic and kinetic properties, Colloids Surfaces, A 333 (2009) 150-155.

[49] Q. Sun, L. Yang, The adsorption of basic dyes from aqueous solution on modified peat-resin particle, Water. Res. 37 (2003) 1535-1544.

[50] D. Kumar, J.P. Gaur, Chemical reaction- and particle diffusion-based kinetic modeling of metal biosorption by a Phormidium sp.-dominated cyanobacterial mat, Bioresour. Technol. 102 (2011) 633-640.

[51] L. Caceres, M. Escudey, E. Fuentes, M.E. Baec, Modeling the sorption kinetic of metsulfuron-methyl on Andisols 
and Ultisols volcanic ash-derived soils: Kinetics parameters and solute transport mechanisms, J. Hazard. Mater. 179 (2010) 795-803.

[52] L. Li, P.A. Quinlivan, D.R.U. Knappe, Effects of activated carbon surface chemistry and pore structure on the adsorption of organic contaminants from aqueous solution, Carbon 40 (2002) 2085-3000.

[53] B.S. Inbaraj, C.P. Chiu, G.H. Ho, J. Yang, B.H. Chen, Effects of temperature and $\mathrm{pH}$ on adsorption of basic brown 1 by the bacterial biopolymer poly $(\gamma$-glutamic acid), Bioresour. Technol. 99 (2008) 1026-1035.

[54] Y.S. Ho, Effect of $\mathrm{pH}$ on lead removal from water using tree fern as the sorbent, Bioresource Technol. 96 (2005) 1292-1296.
[55] H.M.F. Freundlich, Über die adsorption in lösungen, J. Phys. Chem. 57 (1906) 385-471.

[56] I.J. Langmuir, The adsorption of gases on plane surfaces of glass, mica and platinum, J. Am. Chem. Soc. 40 (1918) 1361-1403.

[57] G. McKay, H. Blair, J.R. Gardiner, The adsorption of dyes onto chitin in fixed bed column and batch adsorbers, J. Appl. Polym. Sci. 29 (1989) 499-508.

[58] T.K. Saha, N.C. Bhoumik, S. Karmaker, M.G. Ahmed, H. Ichikawa, Y. Fukumori, Adsorption characteristics of Reactive Black 5 from aqueous solution onto chitosan, Clean-Soil Air Water 39 (2011) 984-993.

IZVOD

\section{MAKROPOROZNI KOPOLIMER NA BAZI GLICIDILMETAKRILATA FUNKCIONALIZOVAN SA DIETILENTRIAMINOM KAO SORBENT TEKSTILNE BOJE REACTIVE BLACK 5}

Zvjezdana P. Sandić ${ }^{1}$, Marija J. Žunić ${ }^{2}$ Danijela D. Maksin ${ }^{3}$, Aleksandra D. Milutinović-Nikolić ${ }^{2}$, Aleksandar R. Popović ${ }^{4}$, Dušan M. Jovanović ${ }^{2}$, Aleksandra B. Nastasovic ${ }^{5}$

${ }^{1}$ Univerzitet u Banja Luci, Prirodno-matematički fakultet, Banja Luka, Bosna i Hercegovina (Republika Srpska)

${ }^{2}$ Univerzitet u Beogradu, IHTM - Centar za katalizu i hemijsko inženjerstvo, Beograd, Srbija

${ }^{3}$ Univerzitet u Beogradu, Institut za nuklearne nauke Vinča, Departman za hemijsku dinamiku i permanentno

obrazovanje, Beograd, Srbija

${ }^{4}$ Univerzitet u Beogradu, Hemijski fakultet, Beograd, Srbija

${ }^{5}$ Univerzitet u Beogradu, IHTM - Centar za hemiju, Beograd, Srbija

(Naučni rad)

U okviru ovog rada ispitana je mogućnost korišćenja makroporoznog kopolimera glicidilmetakrilata i etilenglikoldimetakrilata funkcionalizovanog reakcijom otvaranja epoksidnih grupa sa dietilentriaminom (PGME-deta) kao sorbenta reaktivne tekstilne boje Reactive Black 5 (RB5). U šaržnim uslovima je ispitano uklanjanje RB5 iz vodenog rastvora pomoću PGME-deta, variranjem $\mathrm{pH}$, vremena kontakta, mase sorbenta, početne koncentracije boje i temperature. PGME-deta je pokazao afinitet za sorpciju RB5 zbog prisustva protonovanih amino grupa koje privlače anjonske sulfonatne grupe u molekulu boje i mogućnosti stvaranja vodoničnih veza između sorbenta i sorbata. Kinetika sorpcije je analizirana pomoću četiri kinetička modela (pseudo-prvog, pseudo-drugog reda, unutarčestične difuzije i Mekej) da bi se odredilo koji model najbolje opisuje sorpciju RB5. Zapažen je izrazit uticaj pH vrednosti na sorpciju RB5, sa maksimumom na pH 2 (pri čemu je efikasnost uklanjanja boje $85 \%$ ), i smanjenjem količine sorbovane boje sa povećanjem pH (količina uklonjene boje na $\mathrm{pH} 11$ posle 60 min iznosi samo 24\%). Izučavanjem kinetike sorpcije pokazalo se da sorpcija RB5 pomoću PGME-deta sledi kinetički model pseudo-drugog reda (PSO), sugerišući da je brzina sorpcije kontrolisana kapacitetom sorbenta i koncentracijom sorbata. Mehanizam procesa dominantno čini unutarčestična difuzija, uz manji uticaj difuzije kroz film. Ovi mehanizmi difuzije su izraženiji pri nižim temperaturama i većim koncentracijama. Langmirov model najbolje opisuje ravnotežnu izotermu, ukazujući na homogenu raspodelu aktivnih mesta na površini PGME-deta i monoslojnu sorpciju. Maksimalni sorpcioni kapacitet izračunat iz Langmirove izoterme iznosi $353 \mathrm{mg} \mathrm{g}^{-1}$. Zapaženo je da se brzina sorpcije povećava sa povećanjem temperature. Izračunata vrednost aktivacione energije od oko $40 \mathrm{~kJ} \mathrm{~mol}^{-1}$ potvrđuje da se radi o procesu koji dominantno kontroliše hemisorpcija.
Ključne reči: Reactive Black 5• Makroporozni Umreženi kopolimer • Dietilentriamin • Kinetički modeli • Ravnotežna sorpcija 